\title{
Biomechanical Effects of Trees on Soil and Regolith: Beyond Treethrow
}

\author{
Jonathan D. Phillips* and Daniel A. Marion† \\ *Department of Geography, University of Kentucky \\ †USDA Forest Service
}

\begin{abstract}
Forest soils are profoundly influenced by the biomechanical as well as the chemical and biological effects of trees. Studies of biomechanical impacts have focused mainly on uprooting (treethrow), but this study shows that at least two other effects are significant: physical displacement of soil by root growth, and infilling of stump rot pits. Rocky soils in the Ouachita Mountains in Arkansas were studied because they allow for the use of rock fragments as a tracer of displacement. Rock fragments displaced by tree growth (baumsteins) are ubiquitous here, and displacement shows characteristic differences between pines and hardwoods. Hardwoods promote primarily lateral displacement, with a higher probability of displaced rock fragments eventually falling into stump holes. Pine displacement has a significant vertical component associated with basal mounding, and a lower probability of baumstein deposition in stump holes. Obvious stump holes are relatively rare, but the high ratio of stumps and snags to uprooted trees indicates that standing dead trees, which would ultimately result in a stump hole, are quite common. This, plus the presence of numerous duff-filled depressions, suggests that such holes are filled rapidly. The presence of surface-derived rock fragments and thick litter and duff accumulations indicate that at least some of the fill is external, as opposed to soil detachment from the pit walls. The primary influence of stump holes, as reflected by rock fragment distributions, is localized subsurface stone accumulations that do not extend laterally. The total area affected by uprooting is larger than that of stump holes, despite the lower frequency, due to the greater area of disturbance per event. Estimated turnover times (time for 100 percent of the forest floor to be affected) are shortest for soil displacement, intermediate for uprooting, and longest for stump hole effects. Although contemporary rates cannot be confidently extrapolated, the geomorphological efficacy of these processes is reflected by the fact that they are rapid enough to result in complete regolith turnover over time scales comparable to the Holocene. Displacement, stump holes, and uprooting help to maintain a continuously mixed surface biomantle, and may in some cases result in distinctive pedological features, local spatial variations in soil morphology, and divergent evolution of the soil cover. Key Words: baumstein, biomechanical effects, forest soils, stump holes, uprooting.
\end{abstract}

$\mathrm{W}$ hereas soils and regoliths were once conceived as a primarily geological mantle and a medium for biological activity, geomorphologists and pedologists increasingly view soils as continuously-mixed biomantles (Johnson 1990, 2002; Paton, Humphries, and Mitchell 1995; Balek 2002; Gabet, Reichmann, and Seabloom 2003). This perspective goes back at least to the late nineteenth century, but only recently have conceptual models of soil and regolith incorporating the idea of continuous bioturbation become widely accepted (Johnson 2002; Gabet, Reichmann, and Seabloom 2003). The study of biological effects on soils has traditionally concentrated on biochemical, ecological, and edaphic influences, but increasingly biomechanical effects have been found to be of comparable or even greater importance (Johnson 1993, 2002; Balek 2002; Gabet, Reichmann, and Seabloom 2003; Phillips and Marion 2004a). With respect to biomechanical effects of vegetation in general and trees in particular, most attention has focused on tree uprooting (treethrow or tree tip). Uprooting is a critical pedologic and geomorphic process in most forested environments (Stephens 1956; Butler and Malanson 1990; Schaetzl 1990; Schaetzl et al. 1990; Small, Schaetzl, and Brixie 1990; Scatena and Lugo 1995; Vasenev and Targul'yan 1995; Gabet, Reichmann, and Seabloom 2003). However, trees have other biomechanical effects, including the physical displacement of regolith materials, and the formation of surface depressions and subsurface voids via root and stump rot.

The purpose of this study was to investigate biomechanical effects of trees beyond treethrow, particularly displacement by tree growth and the potential for transport of regolith material into stump holes. Specifically, we sought to document the extent of surface displacement (as indicated by rock fragments) and formation of stump rot depressions; to estimate the importance of these biomechanical effects relative to 
uprooting; and to identify common patterns of soil and regolith development associated with individual trees.

Displacement by root growth is well known, but there have been few considerations of its potential effects on soil and regolith evolution. Root wedging and the physical displacement of soil by stem growth in the context of pedologic and geomorphic processes has been noted by, among others, Lutz and Griswold (1939) and Paton, Humphries, and Mitchell (1995, 64-65). The latter believe these biomechanical effects are not a major process, as even in dense forests roots typically comprise less than 1 percent of the volume of the upper meter of soil. Nonetheless, the observation of displacement and cracking of pavements by roots in urban areas testifies that root growth is a potentially significant process.

The evolution of resulting soil mounds and pits after uprooting has been extensively investigated (Stephens 1956; Schaetzl 1990; Schaetzl and Follmer 1990; Small, Schaetzl, and Brixie 1990; Norman, Schaetzl, and Small 1995; Vasenev and Targul'yan 1995; Small 1997). The potential role of stump-rot depressions, however, has received little attention. This study was motivated both by the general lack of attention to biomechanical effects of trees (other than uprooting), and by previous work in the study area suggesting that biomechanical effects of individual trees in general, and of rock fragment transport into stump holes in particular, are critical processes in regolith evolution and are key determinants of localscale soil variability (Phillips and Marion 2004a, 2004b; Phillips, Luckow, et al. 2005).

\section{Background}

The death of a tree results in a surface depression, whether the death results from uprooting (by wind, ice, logging, and other processes), decomposition, or fire, the latter two following mortality or harvesting. Field observations show that tree uprooting depressions have areal dimensions at least as large as the basal flare of the tree, and often as large as the lateral extent of the coarse roots. Depths for uprooting depressions vary according to the root system of the tree, the material in which it was rooted, and the nature of the uprooting event, but the maximum depth corresponds with the depth of the coarsest roots.

Stump rot depressions (hereafter simply termed stump holes) have not been well studied, but observations indicate that these depressions are much smaller than those from uprooting. They have the same general surface area as the base of the tree, with a maximum depth the same as that of the main central or tap root of the tree.

Stump holes can be expected to infill with material from the pit walls and immediate vicinity, decomposed organic matter from the tree, in-blown leaves and other litter, and soil transported by erosion and mass wasting. In some cases infilling can result in distinctive features such as root casts (Mossa and Schumacher 1993) or stemflow pipes (Herwitz 1993). The pedologic and geomorphic effects of uprooting pits, and their stratigraphic and morphologic signatures, have been discussed by Stephens (1956); Scatena and Lugo (1995); Schaetzl (1990), Schaetzl et al. (1990); Small, Schaetzl, and Brixie (1990); Vasenev and Targul'yan (1995); and Gabet, Reichmann, and Seabloom (2003).

\section{Trees and Soil Morphology in the Ouachita Mountains}

Our investigations of the coevolution of soils and forest ecosystems, and of the effects of trees on soil morphology, were initiated on sideslopes of the Ouachita Mountains in the Ouachita National Forest, Arkansas. Soil variability there is very high and is dominated by local variation within the $(<0.13 \mathrm{ha})$ study plots. The variations within small areas of similar parent material, topography, and vegetation suggest a significant role for highly localized biological effects (Phillips and Marion 2004b). Vertical distributions of rock fragments are often consistent with redistribution of regolith material by uprooting (Phillips and Marion 2004b; Phillips, Luckow, et al. 2005). Spatial analysis of soil variability indicates that individual trees are an important source of local varations (Phillips and Marion 2004a, 2004b). We previously proposed a model of self-reinforcing pedologic influences of trees (SRPIT) whereby some microsites are preferentially occupied over multiple forest generations, resulting in a mosaic of relatively tree-rich and tree-poor patches (Phillips and Marion 2004b). Based on field observations, we suggested that rock fragment displacement by root growth and stump rot play important roles in creating favorable sites for repeated tree establishment (Phillips and Marion 2004b), but we also noted, again based on field observations, the possibility of soil and rock fragment accumulation in holes created by stump rot.

One indication of the potential importance of stump hole infilling is that no subsurface stone lines or stone zones were observed in fifty-eight full-size (surface area $\geq \mathrm{m}^{2}$ ) soil pits, but subsurface stone concentrations were noted in 57 percent of 320 smaller "posthole" sample pits (roughly circular pits at least $30 \mathrm{~cm}$ in di- 
ameter). This indicates abundant local subsurface rock fragment concentrations, but concentrations that are not laterally extensive enough to result in recognition or designation as a stone line or zone in a standard soil profile description based on pit walls. We interpreted this as likely representing localized input of rock fragments into stump holes and uprooting pits, as opposed to general soil mixing, which would result in more areally extensive stone concentrations (Phillips and Marion 2004a; Phillips, Luckow, et al. 2005).

Phillips and Marion (2004b) compared rock fragment distributions of sixteen paired sample sites where sixteen stump holes or rotted stumps approximately flush with the ground surface were compared to adjacent areas within $1 \mathrm{~m}$. These samples showed some evidence of rock displacement by tree growth and of clast deposition in stump holes, but the evidence was equivocal, suggesting the need for further study.

\section{Conceptual Model}

Our conceptual model focuses on rock fragments in part because variations in rock fragment content is a significant factor in determining variations in soil morphology and taxonomy in the Ouachitas, and is also a crucial factor for forest, soil, and land management in the area (Haley 1979; Townsend and Williams 1982; Laurent et al. 1989; Phillips, Luckow, et al. 2005). Second, as durable, easily recognizable features that are readily distinguished from other soil materials, rock fragments make a reliable first-approximation tracer of mass soil movements. Rock fragments are a conservative tracer in the sense that finer and more soluble materials are far more easily moved within the regolith.

We refer to rock fragments displaced by trees as $b a$ umsteins (German for "tree rock") to avoid confusion with terms that might imply petrified wood or root casts. Figure 1 shows a hypothetical sequence for a tree seedling sprouting in soil with surface rock fragments. As the tree and roots become established, rocks and soil material are displaced; the relative proportion of lateral and vertical displacement depending on the rooting habit of the tree. In the C1-D1 pathway of Figure 1, typical of many oaks (Quercus spp.), rocks are displaced laterally by the enlargement of the base of the trunk. This results in rock fragments in direct contact with and sometimes supported by the trunk, which may readily fall into the resulting stump hole after tree mortality. Trees with significant basal mounding, typical of many pines (Pinus spp.) may follow the C2-D2 sequence. The displacement has a significant vertical component, and due to

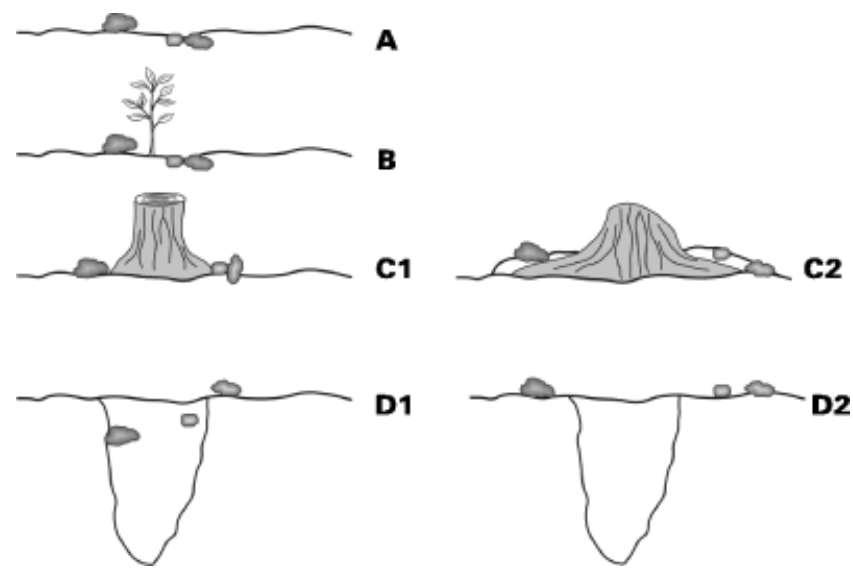

Figure 1. Hypothesized sequence of events for trees growing in soils with surface rock fragments (A). In B, a seedling becomes established among the surface rocks. In $\mathrm{C} 1$, expansion of the trunk base laterally displaces rock fragments, which may be prone to fall into the stump hole following tree mortality (D1). In C2, the roots displace soil upward, forming a basal mound. Following tree death, displaced fragments are less likely to fall into the stump hole (D2).

the slope of the basal mound these rocks are less likely to fall into the stump hole.

Figure 2 suggests some possible sequences of stump hole infilling. The cavity (A) may be filled primarily by slumping of the surrounding material into the stump hole (B), or by colluvium and/or litter from the surface (C). These represent endpoints, and some combination of the mechanisms may occur. As shown in Figure 2, the result could be essentially the restoration of the pre-tree horizon sequence, perhaps marked only by irregularities in horizon boundaries that may not be recognizable as a

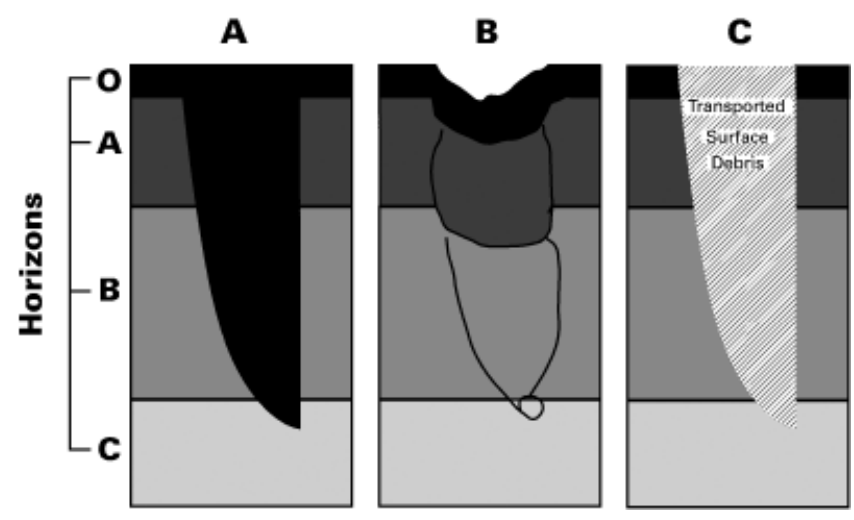

Figure 2. Hypothetical infilling of a stump hole. The blackened area in A shows a tap root depression into an idealized soil profile sequence. In B, the surrounding layers have collapsed into the hole, leaving a minor surface depression and restoring the original soil horizonation, with some boundary irregularities. In C, the stump hole is filled entirely with transported surface debris. Many combinations of $\mathrm{B}$ and $\mathrm{C}$ are possible. 
former stump hole. Conversely, the hole may be preserved by infillings of material different from the surrounding soil and thus be recognizable as a former stump hole. As these are endpoints, various intermediate outcomes are possible. The initial state could feasibly be similar to C, where a stump depression is filled for instance with litter, duff, humus, and loose colluvium. This could then be transformed to a state similar to B as the stump hole walls fail and pedologic processes act on the external infill. Variations could arise due to layering of infill and to differential failure of soil horizons exposed in the walls of the hole.

Tree growth and stump rot may create rock-rich or rock-poor microsites, depending on whether stump holes are infilled with rock fragments. The SRPIT model introduced by Phillips and Marion (2004b) indicates that displacement of rock fragments away from a tree, and subsequent root rot and litter infilling, results in a relatively rock-poor, nutrient-rich microsite that favors subsequent tree establishment. However, evidence also exists that rock fragments are locally transported into stump holes (Phillips and Marion 2004a; Phillips, Luckow, et al. 2005). Where uprooting occurs, rock fragments are often mined from the subsoil and concentrated at the surface (Schaetzl et al. 1990; Small, Schaetzl, and Brixie 1990). The relative importance and potentially off-setting effects of these mechanisms is not known.

\section{Study Area and Methods}

\section{Study Area}

Study sites are in the Ouachita National Forest (Figure 3). The Ouachita Mountains are parallel, eastwest trending ridges with intermontane basins, approximately $100-\mathrm{km}$ wide (north-south) and $320-\mathrm{km}$ long (east-west). Local relief varies from 75-530 m, generally increasing from east to west. The climate is humid subtropical. Mean annual precipitation is $1,300-1,400$ $\mathrm{mm}$, occurring primarily as rain during warm-season thunderstorms or fall and winter frontal events. Precipitation is distributed fairly evenly throughout the year, with the maximum monthly precipitation typically occurring during the spring.

The region is characterized by extensively faulted and folded Paleozoic sedimentary rocks (Stone and Bush 1984). The strata are typically alternating layers of sandstone and shale (Jordan et al. 1991), with lesser amounts of quartzite, novaculite, and chert. Sample sites are within the Stanley Shale, Jackfork Sandstone, and Atoka Formation lithologic units (Figure 3). All three are common in the Ouachita Mountains, and are similar in that they all consist of steeply dipping, extensively faulted, intermixed beds of fine- to medium-grained sandstones and fine-grained shales. The formations differ in age and in the relative proportions of each rock type (Jordan et al. 1991; McFarland 1998). Exposed shales are deeply weathered and highly erodible, whereas the sandstones are noticeably less altered and more durable. Ridgetops are composed of the more resistant sandstones, quartzites, and novaculites. Side slopes are often underlain by shale, with sandstone outcrops common.

The soils, described in earlier work (Phillips and Marion 2004a), are predominantly Hapludults. Surface textures are generally loam or sandy loam, and subsoil textures range from sandy clay loam to clay. Not unexpectedly, broad textural variations reflect the extent to which the parent material is dominated by sandstone or shale. The rock fragment characteristics are discussed by Phillips, Luckow, et al. (2005).

All sample sites are forested. Current forest vegetation consists of oak-hickory (i.e., hardwood-dominated), shortleaf pine (pine-dominated), and oak-pine (mixed pine-hardwood) forest types. The pine-dominated sites include pine-bluestem savannas, apparently the dominant community on southern exposures at the time of European settlement, and sites where shortleaf pine dominates the overstory but where hardwoods may dominate the mid- and understory (USDA Forest Service 1999). The present composition of the forest vegetation has only existed during the last 4,000 years (Delcourt and Delcourt 1991). Before Euro-American settlement approximately 200 years ago, forest stands were likely generally more open than today and had somewhat different composition and structure. The dramatic decrease in fire frequency after Euro-American settlement may explain these changes (Foti and Glenn 1991).

\section{Methods}

The present study makes use of eleven sample plots from a total of sixteen that were established in 2001 as part of our previous research in the study area. ${ }^{1}$ Each study plot was circular with a radius of $20 \mathrm{~m}(66 \mathrm{ft})$ and an area of 0.127 ha. Three to four full-size soil pits and twenty smaller pits were excavated at each plot, and topography was surveyed at a detailed $(1-\mathrm{m})$ scale. Uprooted trees, stumps, and standing dead trees were also inventoried for each plot. The sample design is described in detail elsewhere (Phillips and Marion 2004a, 2004b; Phillips, Luckow, et al. 2005; Phillips, Marion, et al. 


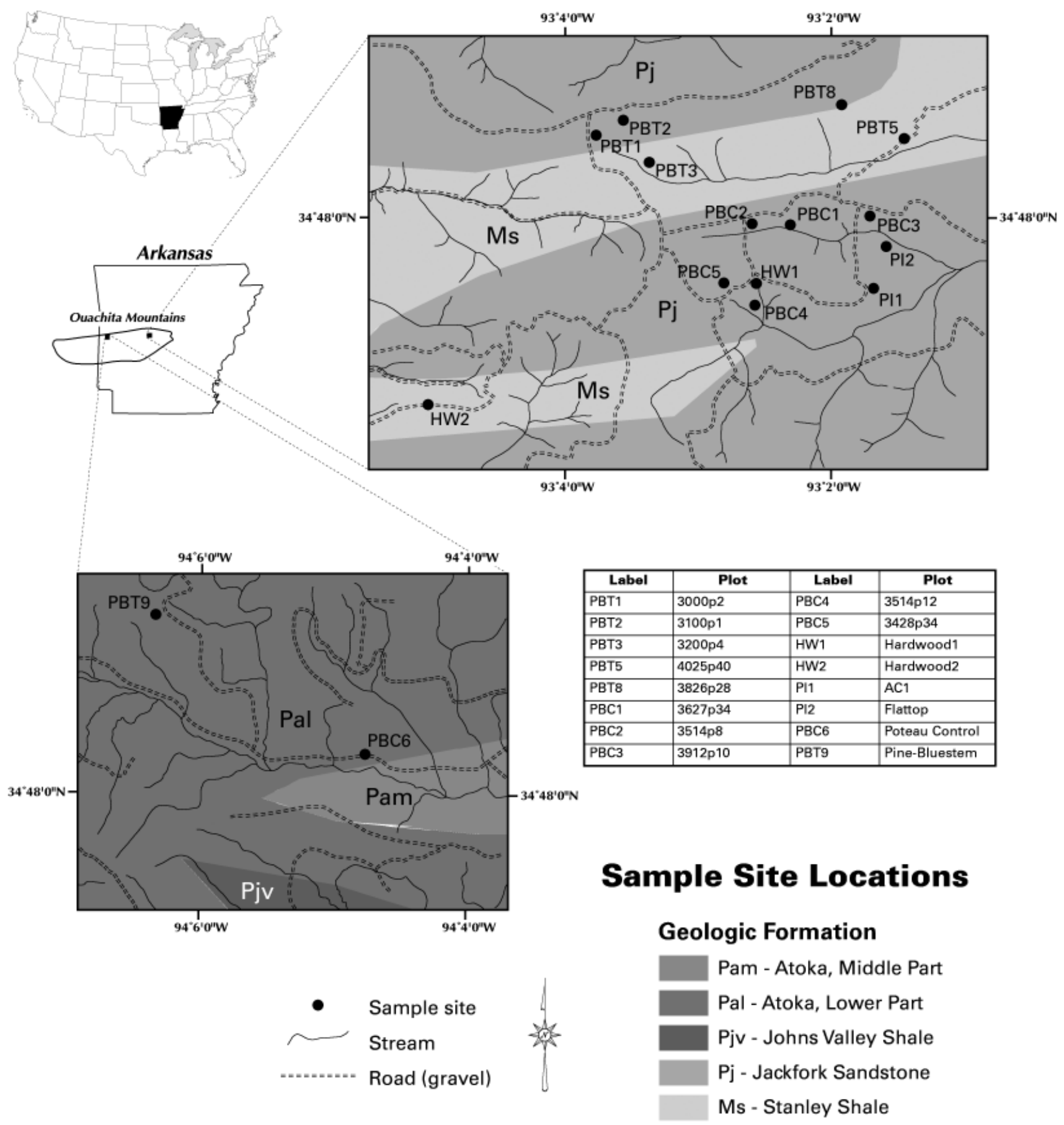

Figure 3. Location of the study sample sites.

2005) and is only briefly reviewed here. The sites are mainly on side slopes (as opposed to ridgetops or valleys); one site straddles a minor ridgetop. In five cases the vegetation community at the time of sampling was a mixed shortleaf pine/hardwood forest, the dominant contemporary community type in the region. The other six sites represented the other dominant forest communities in the area: a pine-bluestem savanna, two closed- canopy pine-dominated sites, two hardwood-dominated sites, and a pine-dominated site that has been identified by the Ouachita National Forest as not having been logged, burned, farmed, or otherwise disturbed by humans since at least 1800 . Soil and topographic mapping, rock fragment distributions, regolith stratrigaphy, and inventories of uprootings, stumps, snags, and woody debris were carried out in our earlier studies (Phillips and 
Marion 2004a, 2004b; Phillips, Luckow, et al. 2005; Phillips, Marion, et al. 2005).

The eleven plots used for the current study were revisited in 2004. The slope profile from each plot center to the nearest ridgetop or upslope sandstone outcrop was surveyed using a laser level and prism rod along the line of the steepest uphill slope. The mean slope within each plot was also calculated from previous topographic surveys.

Surface rock fragment cover was estimated using a metal-tipped rod. The entire plot was walked using a criss-cross pattern, and the rod was poked into the surface by the operator every $2 \mathrm{~m}$ by the toe of the right foot (approximately one-hundred samples per plot). A hit or miss was recorded based on whether the rod tip contacted a rock fragment, of any size from gravel to boulders to bedrock outcrops. No hit was recorded if any soil other than leaf litter was penetrated before rock contact. The percentage surface rock fragment cover was estimated as the percentage of hits.

All stump holes in each plot were inventoried. Numerous minor depressions with thick litter, duff, and/or O horizon layers are found in all plots, and most of these are believed to be infilled stump holes or uprooting pits. However, the only holes recorded were those that were unequivocally stump holes, as indicated by surviving bark rings or decayed wood remnants around the edges, or approximately conical or cylindrical hollows with some decayed wood remains. The diameter of the hole was measured. In some cases where the original trunk diameter was indistinct, an inner (minimum) and outer (maximum) diameter were recorded, which were presumed to correspond roughly with the trunk/tap root diameter, and the root crown/basal flare diameter, respectively. In subsequent statistical analyses, the smaller interior diameter was used. The general nature of the fill was recorded, and any rock fragments with a median diameter $\geq 60 \mathrm{~mm}$ were extracted and measured, and the general lithology was recorded. Depth was measured where it could be reliably determined by excavation or using the metal-tipped probe. This was primarily in cases where there was a clear and abrupt transition between loose, organic-rich infill and denser mineral soil.

All trees on the plot were examined for baumsteins with a minimum median diameter of $6 \mathrm{~cm}$, a size chosen to correspond approximately with the boundary between gravel and cobble size fractions $(6.4 \mathrm{~cm})$. A fragment $>6$ $\mathrm{cm}$ was considered a baumstein if:

1. an exposed or partially exposed clast was in direct contact with the tree trunk, basal flare, or root crown, or overlying an exposed surface root.
2. a clast was in direct contact with the tree trunk, basal flare, or root crown and covered by litter and/ or duff, but was clearly above the mineral soil surface.

3. a clast was entirely within the surface root mound of a tree.

Clasts were excluded if overlain by a root with a diameter $\geq 2 \mathrm{~mm}$, if wood was growing over or molding itself to the rock surface, or if scar tissue on the tree suggested the rock may have fallen against the tree base. These criteria probably eliminated some displaced rock fragments, but the criteria and field procedures were designed so that any bias would be consistently on the side of underestimating, rather than overestimating, the number of baumsteins.

Where baumsteins were found, the tree was identified as pine or hardwood, and the diameter at breast height (dbh) measured with a dendrological tape measure. The median diameter of all clasts $\geq 6 \mathrm{~cm}$ was determined, along with the general lithology (almost all clasts were sandstone). If the rock was unambiguously on the upslope or downslope side of the tree, this was also recorded. In some cases trees had continuous rock rings around the base, invariably with sizes down to gravel (though trees with only gravel clasts $<6 \mathrm{~cm}$ were not counted). In such cases the largest fragment was identified and measured. Clast measurements were made by measuring all major axes and recording the median measurement.

Data on the number and size of uprooted root wads, stumps, and snags were taken from earlier studies (Phillips and Marion 2004a, 2004b). In addition, USDA Forest Service studies on sideslopes in the Arkansas Ouachitas have inventoried vegetation, stumps, and litter, and these data were obtained from reports by Guldin, Baker, and Shelton (1994), Guldin and Foti (2004), Shelton and Lawson (1994), and Thill, Tappe, and Koerth (1994).

\section{Results}

\section{Rock Fragments and Ridgetops}

Soils at the study sites are rocky. Surface rock fragment cover ranges from 5 to 73 percent, with a mean of 39 percent (Table 1). The rock fragments are overwhelmingly sandstone, though many sandstone fragments have quartz veins, and occasionally quartz fragments were found. Some fragments may be local weathering remnants, but in most cases the clasts are transported downslope from the sandstone/quartz 
Table 1. Surface rock fragment, baumstein, stump hole, and standing dead tree characteristics within the eleven study sites

\begin{tabular}{|c|c|c|c|c|c|c|c|}
\hline Plot name & Vegetation & Rock fragment cover ${ }^{a}$ & $\mathrm{BSt}^{\mathrm{b}}$ & Hardwood BSt ${ }^{\mathrm{b}}$ & Pine $\mathrm{Bst}^{\mathrm{b}}$ & Stump holes ${ }^{c}$ & Stump count ${ }^{\mathrm{d}}$ \\
\hline $3514 \mathrm{p} 8$ & Mixed pine \& hardwood & 38 & 9 & 5 & 4 & 7 & 21 \\
\hline $3627 \mathrm{p} 34$ & Mixed pine \& hardwood & 73 & 47 & 20 & 27 & 6 & 21 \\
\hline $3912 \mathrm{p} 10$ & Mixed pine \& hardwood & 63 & 43 & 25 & 17 & 1 & 23 \\
\hline $3428 \mathrm{p} 34$ & Mixed pine \& hardwood & 52 & 37 & 15 & 22 & 0 & 19 \\
\hline $3514 \mathrm{p} 12$ & Mixed pine \& hardwood & 20 & 14 & 8 & 6 & 1 & 23 \\
\hline HW1 & Hardwood dominated & 42 & 36 & 34 & 2 & 0 & 21 \\
\hline HW2 & Hardwood dominated & 28 & 39 & 39 & 0 & 0 & 16 \\
\hline Poteau control & $\begin{array}{l}\text { Mixed Pine/hardwood; } \\
\text { pines dominate overstory }\end{array}$ & 30 & 20 & 8 & 11 & 1 & 24 \\
\hline Pine/bluestem & Pine/bluestem savanna & 5 & 10 & 1 & 9 & 0 & 5 \\
\hline AC1 & $\begin{array}{l}\text { Mixed pine/hardwood; } \\
\text { pines dominate overstory }\end{array}$ & 18 & 23 & 10 & 13 & 2 & 32 \\
\hline Flattop & $\begin{array}{l}\text { Mixed pine/hardwood; } \\
\text { pines dominate overstory }\end{array}$ & 62 & 29 & 19 & 10 & 1 & 25 \\
\hline Mean & & 39 & 27.9 & 16.7 & 11.0 & 1.7 & 20.9 \\
\hline
\end{tabular}

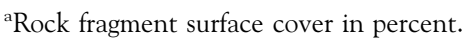

bumber of trees with baumsteins (BSt). The total number of baumsteins includes dead trees or stumps with rock rings, and may include unidentifiable trees. 'Includes only unequivocal stump rot holes with bark rings or woody remnants.

Includes standing dead trees (snags).

ridgetops or other upslope sandstone outcrops (Phillips, Luckow, et al. 2005).

The plot centerpoints were 58 to $175 \mathrm{~m}$ from the ridge crest or nearest upslope rock outcrop, with the exception of one plot that straddles a minor ridgetop. Slope gradients ranged from 0.05 to 0.29 , as detailed in Table 2. Figure 4 shows the relationships between surface rock fragment cover and distance and slope to the ridgetop. Eleven data points are insufficient for statistical inference, but the positive relationship between rock cover and slope to ridgetop, along with the general lack of a consistent relationship with distance, suggests that steepness is more important than distance from the source in determining the coverage of transported rock fragments. Because soil thickness is not closely related to slope gradient or curvature at these sites (Phillips, Marion, et al. 2005), we speculate that the relationship reflects the relative surface mobility of fragments.

\section{Vegetation}

The vegetation of each plot is indicated in Table 1 , and the inventory of uprootings and stumps is given in Table 3. The stump count includes snags (standing dead trees). Basal area was computed from stump diameters or the dbh of snags by assuming circular cross sections. Only trees $>5 \mathrm{~cm}$ dbh were included. The uprooting surface area is based on measurements of root wads and does not include mounds or pits that may well be associated with treethrow, but where no trace of an uprooted tree was present.
"Standing dead" as indicated by stumps and snags is far more common than uprooting. However, the total surface area of the forest floor influenced by uprooting is considerably greater than the basal area of stumps. Thill, Tappe, and Koerth (1994) collected data on stumps and snags at eighteen stands in the Ouachitas in ecological settings similar to the study sites, and obtained a mean stump plus snag density of $119.5 \mathrm{ha}^{-1}$, ranging from a handful up to $380 \mathrm{ha}^{-1}$. In the same units, the count in Table 3 is similar, with a mean of 160.3 stumps and snags $\mathrm{ha}^{-1}$, and a range of 39.4 to 252.0. One difference is that in the Thill, Tappe, and Koerth (1994) data, stumps outnumber standing dead trees by more than five to one,

Table 2. Study site topography

\begin{tabular}{|c|c|c|c|c|}
\hline Plot & $\begin{array}{c}\text { Distance }^{a} \\
(\mathrm{~m})\end{array}$ & $\begin{array}{l}\text { Slope to } \\
\text { ridgetop }\end{array}$ & $\begin{array}{c}\text { Mean plot } \\
\text { slope }\end{array}$ & $\begin{array}{c}\text { Topographic } \\
\text { setting }\end{array}$ \\
\hline $3514 p 8$ & 80 & 0.07382 & 0.06018 & concave midslope \\
\hline $3627 \mathrm{p} 34$ & 98 & 0.28659 & 0.18995 & complex midslope \\
\hline $3912 \mathrm{p} 10$ & 78 & 0.26927 & 0.13572 & concave midslope \\
\hline $3428 \mathrm{p} 34$ & 0 & 0.05000 & 0.04798 & convex ridgetop \\
\hline $3514 \mathrm{p} 12$ & 58 & 0.06140 & 0.07498 & straight midslope \\
\hline HW1 & 111 & 0.14987 & 0.15988 & convex midslope \\
\hline HW2 & 74 & 0.17375 & 0.20450 & complex midslope \\
\hline Poteau control & 82 & 0.14176 & 0.20791 & straight midslope \\
\hline Pine/bluestem & 113 & 0.09512 & 0.10973 & concave midslope \\
\hline $\mathrm{AC} 1$ & 78 & 0.10731 & 0.14608 & straight midslope \\
\hline Flattop & 175 & 0.22495 & 0.24362 & straight midslope \\
\hline
\end{tabular}

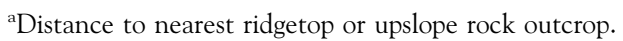

'Includes convex, concave, and straight segments with none clearly dominant. 

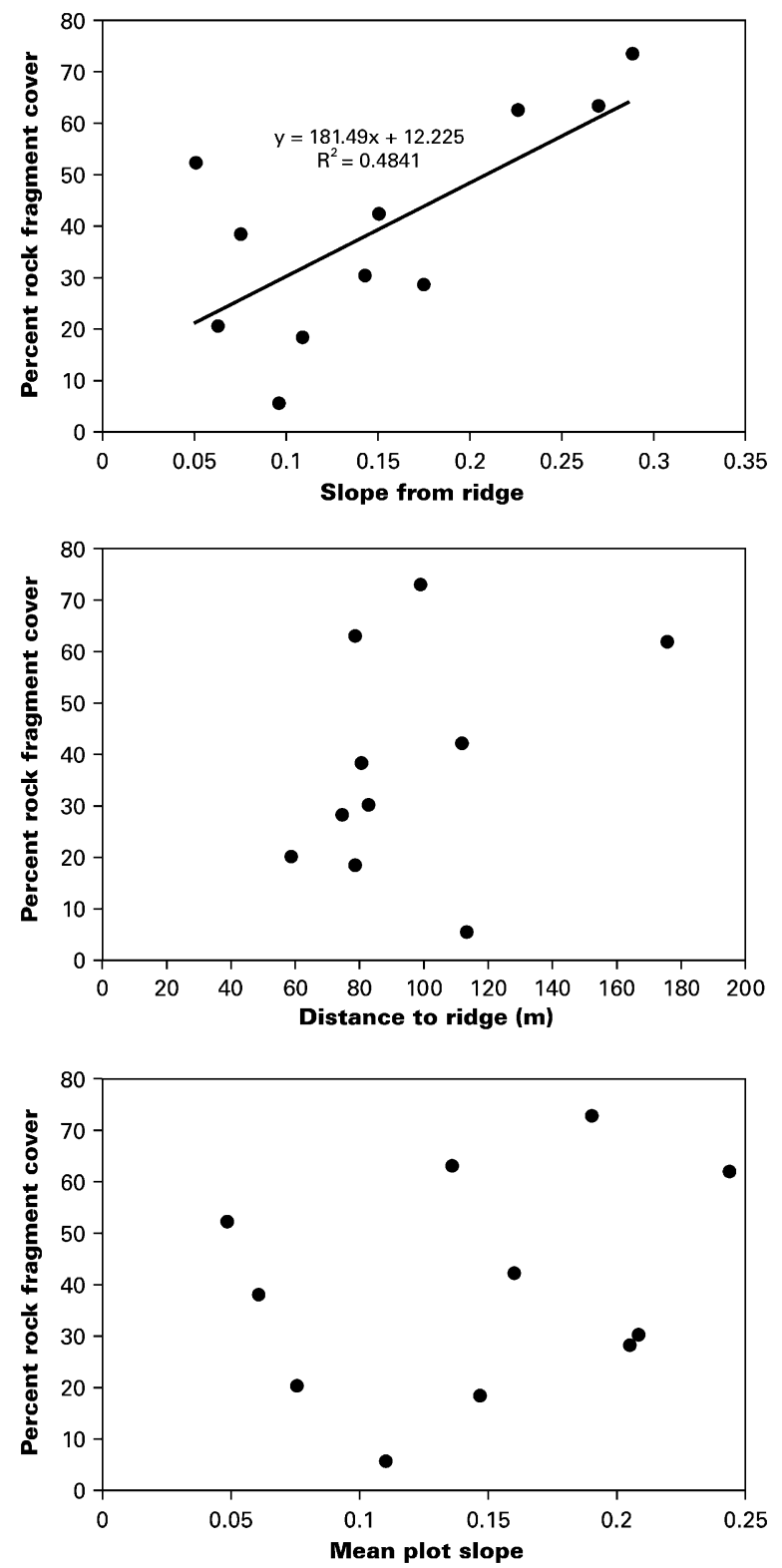

Figure 4. Relationships between surface rock fragment cover and slope and distance to the nearest upslope ridgecrest or sandstone outcrop, and mean slope within the plot.

whereas we measured, on average, approximately equal numbers of stumps and snags. We speculate that the difference is related to the timing and history of logging at the sites.

The general vegetation characteristics of mixed pine/ hardwood and pine-dominated stands on hillslope sites in the Ouachita Mountains are shown in Table 4. Typical densities are 600 to 800 tree stems per hectare, with basal areas of 16 to $30 \mathrm{~m}^{2} \mathrm{ha}^{-1}$. Pines and other conifers-overwhelmingly shortleaf pine (Pinus echinata)typically comprise slightly more than half of the stem count but 60 to 75 percent of the basal area. This is
Table 3. Treethrows (uprooting) and stump frequency and basal areas at the eleven study sites

\begin{tabular}{lcccc}
\hline & \multicolumn{5}{c}{$\begin{array}{c}\text { Treethrow surface } \\
\text { Plot }\end{array}$} & Treethrows & $\begin{array}{c}\text { Stump basal } \\
\left(\mathrm{m}^{2}\right)\end{array}$ & area $\left(\mathrm{m}^{2}\right)$ \\
\hline $3514 \mathrm{p} 8$ & 0 & 21 & 0 & 0.86 \\
$3627 \mathrm{p} 34$ & 3 & 21 & $>0.2^{\mathrm{b}}$ & 1.53 \\
$3912 \mathrm{p} 10$ & 1 & 23 & 0.60 & 0.94 \\
$3428 \mathrm{p} 34$ & 0 & 19 & 0 & 0.24 \\
$3514 \mathrm{p} 12$ & 0 & 23 & 0 & 0.83 \\
HW1 & 0 & 21 & 0 & 0.51 \\
HW2 & 0 & 16 & 0 & 0.46 \\
Poteau cont. & 1 & 24 & 0.33 & 0.3 \\
Pine/blue. & 0 & 5 & 0 & 0.14 \\
AC1 & 3 & 32 & 8.90 & 0.90 \\
Flattop & 1 & 25 & 3.12 & 0.43 \\
Total $^{\mathrm{c}}$ & 21 & 240 & 38.60 & 9.12 \\
\hline
\end{tabular}

Source: Compiled from data in Phillips and Marion (2004b).

ancludes standing dead trees; excludes sawed stumps.

boil had fallen from rootwads; minimum area estimated from tree diameters.

${ }^{\mathrm{c}}$ Total for sixteen study plots including the eleven listed here and five additional plots not used in this study.

consistent with the field plots in our study, with the exception of the hardwood-dominated plots. The hardwoods are chiefly oaks (Quercus spp.), particularly southern red oak (Q. falcata), white oak (Q. alba), northern red oak (Q. rubra), and post oak (Q. stellata). At our field sites blackjack oak (Quercus marilandica) was also common, but was not mentioned as one of the most common species by Guldin, Baker, and Shelton (1994) or Guldin and Foti (2004). Mockernut hickory (Carya tomentosa) and other hickories (Carya spp.) are also common.

Root forms of trees are typically classified as tap, heart, or flat (Pritchett and Fisher 1987). Tap roots are characterized by a single dominant root descending directly below the trunk, with subsidiary roots spreading from the tap root. Heart roots have a cluster of roots radiating from the root crown beneath the trunk, and flat root forms are dominated by shallow lateral roots. All the common species found at the Ouachita sites are generally characterized by the tap root form, though individual trees may adapt their root architecture to constraints of the substrate. Observations of root systems revealed in exposed root plates, soil pits, and other exposures in the study area indicated that all are of the tap root type. The characteristic species at the study sites are typical in that the bulk of the root system is concentrated in the upper meter of soil (Pritchett and Fisher 1987; Burns and Honkala 1990). Again, this root concentration is consistent with our observations of uprootings and in soil pits (Phillips and Marion 2004a, 2004b). 
Table 4. Vegetation characteristics of mixed pine-hardwood and pine stands on generally south-facing slopes in the Ouachita National Forest

\begin{tabular}{|c|c|c|c|c|}
\hline Source & Quantity & Mean & Minimum & Maximum \\
\hline \multirow[t]{9}{*}{ Guldin, Baker, and Shelton (1994) 52 stands } & tree age $(\mathrm{yr})$ & & 64.5 & \\
\hline & height $(\mathrm{m})$ & 21.5 & & \\
\hline & trees ha ${ }^{-1}$ & 798.3 & & \\
\hline & basal area $\left(\mathrm{m}^{2} \mathrm{ha}^{-1}\right)$ & 29.1 & & \\
\hline & percent pines/conifers & 51.1 & & \\
\hline & perct basal area pines & 73.5 & & \\
\hline & perencent vegetation cover & 91.0 & & \\
\hline & dbh pines $(\mathrm{cm})$ & 26.5 & & \\
\hline & dbh hardwoods & 16.0 & & \\
\hline \multirow[t]{6}{*}{ Guldin and Foti (2004) four experimental watersheds } & pine basal area $\left(\mathrm{m}^{2} \mathrm{ha}^{-1}\right)$ & 11.5 & & \\
\hline & hardwood basal area $\left(\mathrm{m}^{2} \mathrm{ha}^{-1}\right)$ & 8.5 & & \\
\hline & total basal area $\left(\mathrm{m}^{2} \mathrm{ha}^{-1}\right)$ & 19.0 & 16.5 & 23.5 \\
\hline & pine trees ha ${ }^{-1}$ & 350.7 & & \\
\hline & hardwood trees ha ${ }^{-1}$ & 338.4 & & \\
\hline & total trees ha ${ }^{-1}$ & 689.1 & 578.1 & 729.2 \\
\hline \multirow[t]{5}{*}{ Thill, Tappe, and Koerth (1994) 20 stands $^{a}$} & pine basal area $\left(\mathrm{m}^{2} \mathrm{ha}^{-1}\right)$ & 17.6 & 12.5 & 24.2 \\
\hline & hardwood basal area $\left(\mathrm{m}^{2} \mathrm{ha}^{-1}\right)$ & 8.4 & 4.3 & 14.2 \\
\hline & total basal area $\left(\mathrm{m}^{2} \mathrm{ha}^{-1}\right)$ & 26.0 & 18.1 & 37.1 \\
\hline & litter depth $(\mathrm{cm})$ & 2.1 & 1.7 & 3.1 \\
\hline & stumps + snags ha ${ }^{-1}$ & 119.5 & 2.3 & 380.7 \\
\hline \multirow[t]{3}{*}{ Shelton and Lawson (1994) 24 stands $^{a}$} & intact litter $\left(\mathrm{t} \mathrm{ha}^{-1}\right)$ & 5.2 & 3.7 & 7.8 \\
\hline & fermented layer $\left(\mathrm{tha}^{-1}\right)$ & 14.1 & 10.4 & 17.6 \\
\hline & total litter $\left(\mathrm{tha}^{-1}\right)$ & 19.3 & 16.2 & 23.5 \\
\hline
\end{tabular}

Notes: All sites are on generally south-facing slopes in the Ouachita National Forest. Only trees with $\mathrm{dbh}>9 \mathrm{~cm}(3.6 \mathrm{in}$.) are included.

${ }^{a}$ These are subsets of the fifty-two stands sampled by Guldin and Foti (2004).

\section{Stump Holes}

As shown in Table 1, some plots had no stump holes, and others had as many as seven, with a mean of 1.7 per plot. All plots had numerous minor depressions $<1 \mathrm{~m}$ in diameter, and many $<0.5 \mathrm{~m}$ in diameter, typically with thick litter and duff accumulations. Many of these are likely former stump holes. We did not enumerate or measure these depressions unless they were clearly and unambiguously stump holes, but given the relative proportion of standing dead versus uprooting (see Table 1), we believe the majority of these depressions to be former stump holes. In some depressions there was a thickerthan-typical (for the surrounding zone) litter layer overlying mineral soil with horizon sequences typical of the surrounding soils.

Diameters of the nineteen measured stump holes ranged from 12 to $81 \mathrm{~cm}$, with a mean of $34.6 \mathrm{~cm}$. Some stump holes associated with smaller trees may have been missed because of their small size. Depth could be reliably measured in eleven cases, ranging from $<25$ to $>200 \mathrm{~cm}$, with typical depths of 40 to $75 \mathrm{~cm}$. Based on bark remnants, four could be indentified as pine and one as hardwood, but in most cases no reliable identification of the tree could be made. We suspect that the majority were shortleaf pines, as fourteen of nineteen had diameters $\geq 30 \mathrm{~cm}$. Hardwoods this large are rare, except in the two hardwood-dominated sites where no stump holes were measured.

Organic debris, including litter, duff, and humus in all cases and partially-decomposed wood and/or charcoal in some, comprised the major volume of fill in all cases. All nineteen stump holes contained some gravel fill, and eleven contained clasts of $\geq 6 \mathrm{~cm}$ median diameter. The latter ranged up to $18.5 \mathrm{~cm}$; one stump hole in particular (at plot 3627p34) contained essentially a mixture of mainly cobble-sized rocks, gravel, and organic debris.

In two cases, soil pits chanced to bisect infilled stump holes, which could clearly be identified as such. One example is shown in Figure 5, where a relatively small diameter $(11 \mathrm{~cm})$ stump hole contains two sandstone fragments.

\section{Baumsteins}

On average, plots contained about twenty-eight baumstein trees (trees with displaced surface rock fragments $>6-\mathrm{cm}$ diameter) each, ranging from a minimum of 9 and 10 to a maximum of 43 and 47. This underestimates the occurrence of rock fragments displaced by 


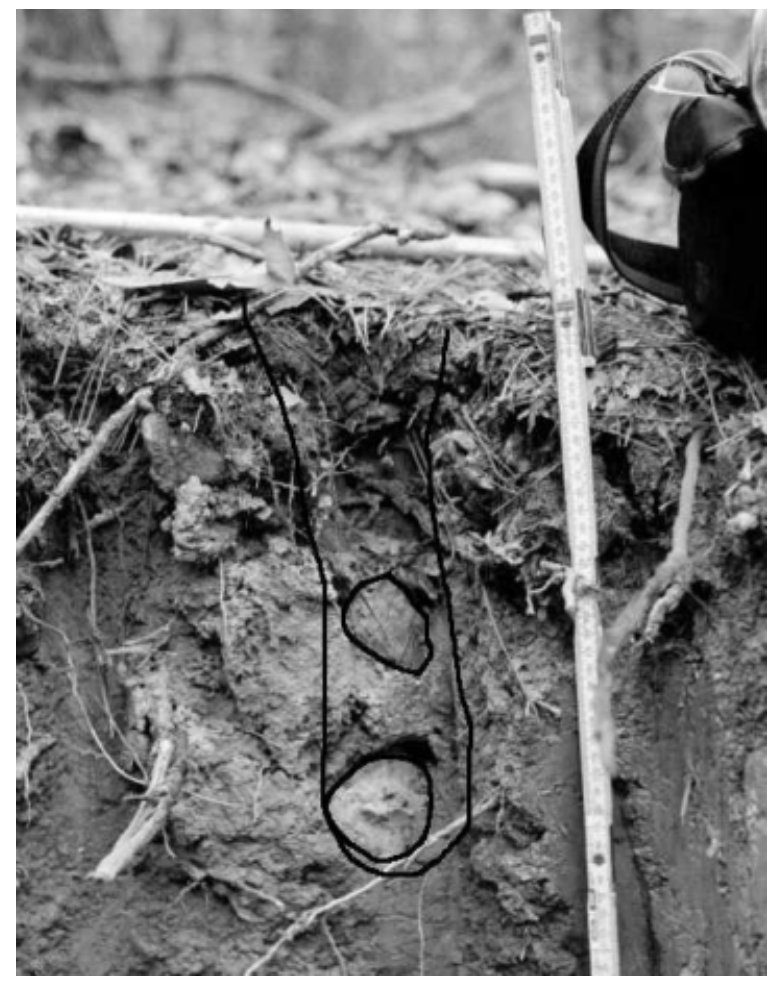

Figure 5. Stump hole encountered in soil pit excavation. For clarity, the approximate boundary of the hole and of two sandstone rock fragments are outlined.

trees, as only those cases where at least one clast had a median diameter $>6 \mathrm{~cm}$ were recorded.

The mean number of hardwood baumstein trees per plot is greater than for pine, by sixteen to eleven, but the mean values reflect very large imbalances at the two hardwood plots (34 to 2, and 39 to 0 , respectively, at

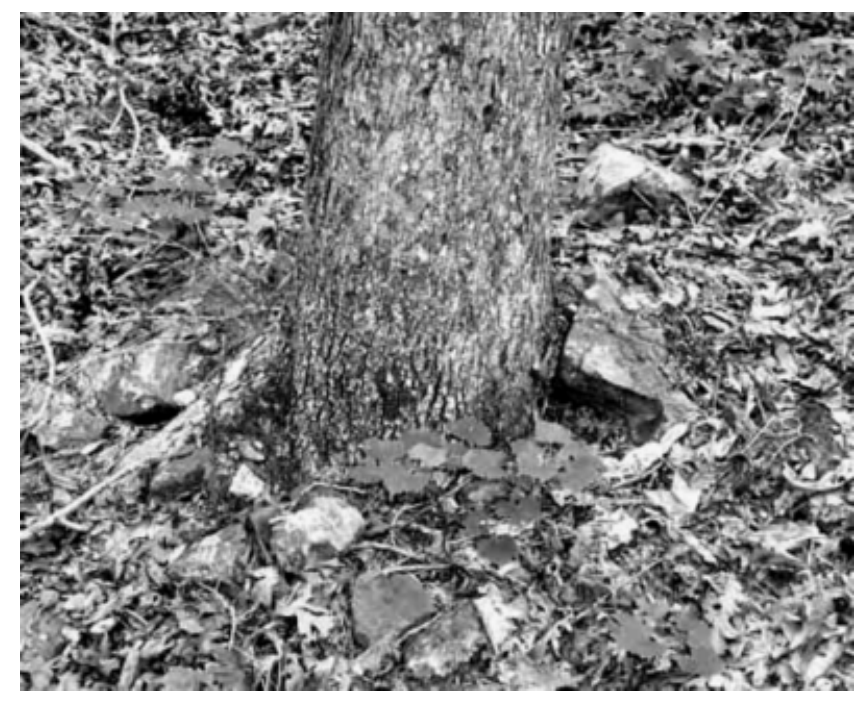

Figure 6. Sandstone fragments displaced by tree growth around an oak at the HW1 plot.

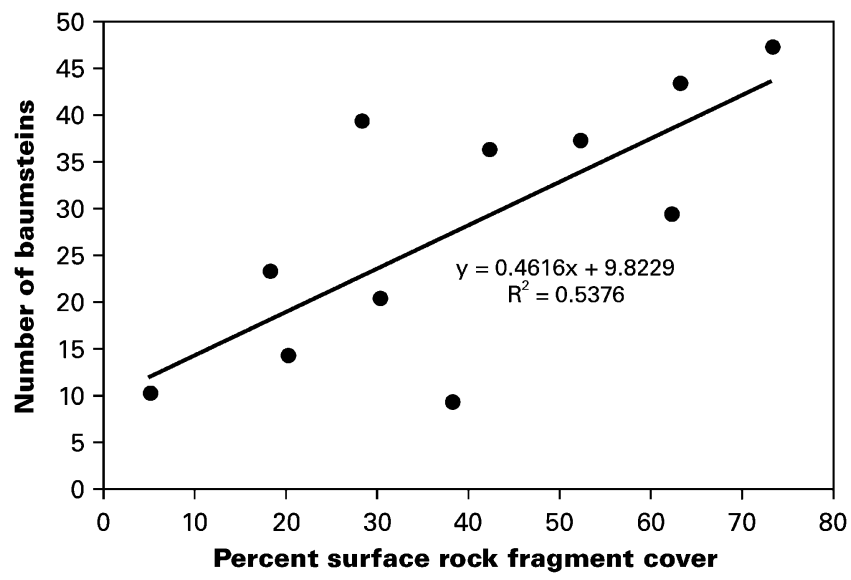

Figure 7. Relationship beteen the number of baumsteins and the percentage of surface rock fragment cover for the eleven study plots.

HW1 and HW2). Pines with baumsteins outnumbered hardwoods at six of the nine other plots. Hardwood baumsteins were generally easier to spot in the field (Figure 6). Whereas the basal flares and root crowns of oaks and other hardwoods were roughly conincident with the ground surface and not covered by unusually large litter layers, pines (particularly those with $\mathrm{dbh}>15$ $\mathrm{cm}$ ) had mounded bases with thick litter and duff accumulations that had to be scraped away to search for rock fragments. Hardwood baumsteins resemble $\mathrm{C} 1$ in Figure 1 and pines resemble C2 in Figure 1. The correspondence between pines and mounding at the tree base and root crown is so strong that it can be assumed in the study area that pines (particularly but not exclusively larger trees with dbh $>15 \mathrm{~cm}$ ) have mounded bases, whereas hardwoods do not.

Rocks displaced by trees are overwhelmingly sandstone, reflecting the lithological makeup of the surface and A horizon rock fragments more generally (Phillips, Luckow, et al. 2005). Not unexpectedly, we found a positive relationship between the number of trees with baumsteins and the proportion of the surface covered by rock fragments $\left(R^{2}=0.54\right.$; Figure 7$)$.

Of the 141 baumstein trees where detailed measurements were made, forty-eight (34 percent) had continuous rock rings, defined as gravel or larger rock fragments circling the entire trunk base. In cases where the fragments were discontinuous, the location of the largest rock fragment was recorded as uphill, downhill, or neither. A predominance of upslope fragments might suggest that trees are merely blocking material moving downslope, as opposed to being displaced by tree growth. This does not appear to be the case. The largest rock was found upslope in nineteen cases (13.5 percent), six of which also had a rock $>6 \mathrm{~cm}$ in diameter on the 
Table 5. Area of baumstein influence

\begin{tabular}{lcccccc}
\hline Plot & $\begin{array}{c}\text { No. of } \\
\text { baumstein trees }\end{array}$ & $\begin{array}{c}\text { Mean basal } \\
\text { area }\end{array}$ & $\begin{array}{c}\text { Mean soil } \\
\text { influence area }\end{array}$ & $\begin{array}{c}\text { Total basal } \\
\text { area }\end{array}$ & $\begin{array}{c}\text { Total soil } \\
\text { influence area }\end{array}$ & $\begin{array}{c}\text { Percentage soil } \\
\text { influence }\end{array}$ \\
\hline $3514 \mathrm{p} 8$ & 9 & 0.12000 & 0.48000 & 1.08 & 4.32 & 0.34 \\
$3627 \mathrm{p} 34$ & 47 & 0.07953 & 0.31813 & 3.74 & 14.95 & 1.19 \\
$3912 \mathrm{p} 10$ & 43 & 0.03261 & 0.13045 & 1.40 & 5.61 & 0.45 \\
$3428 \mathrm{p} 4$ & 37 & 0.07799 & 0.31195 & 2.89 & 11.54 & 0.92 \\
HW1 & 36 & 0.06932 & 0.27727 & 2.50 & 9.98 & 0.79 \\
$3514 \mathrm{p} 12$ & 14 & 0.06577 & 0.26309 & 0.92 & 3.68 & 0.29 \\
AC1 & 23 & 0.05016 & 0.20066 & 1.15 & 4.62 & 0.37 \\
Poteau con. & 20 & 0.07450 & 0.29801 & 1.49 & 5.96 & 0.47 \\
Pine Blue. & 10 & 0.16056 & 0.64223 & 1.61 & 6.42 & 0.51 \\
HW2 & 39 & 0.08027 & 0.32109 & 3.13 & 12.52 & 1.00 \\
Flattop & 29 & 0.06648 & 0.26594 & 1.93 & 7.71 & 0.61 \\
Mean & 27.9 & 0.07974 & 0.31898 & 1.98 & 7.94 & 0.63 \\
\hline
\end{tabular}

downslope side. By contrast, forty-three baumstein trees (30 percent) had the largest rock on the downhill side, and in thirty-one cases ( 22 percent) the displaced rocks were neither up nor downslope. In general, results suggest that rocks are displaced in all directions, with some inconclusive evidence of a slight tendency for more displacement in the downslope direction.

The mean basal area of baumstein trees per plot, based on their $\mathrm{dbh}$, is $15.6 \mathrm{~m}^{2} \mathrm{ha}^{-1}$, compared to total tree basal areas in the region of 16 to $30 \mathrm{~m}^{2} \mathrm{ha}^{-1}$ (Table 4). The stem density of baumstein trees in the study plots is $220 \mathrm{ha}^{-1}$, compared to regional densities of 600 to 800 (Table 4). These data presumably reflect the tendency for larger trees to displace rocks. This is borne out by comparing the mean dbh for hardwood and pine baumstein trees in our study $(21.8$ and $34.6 \mathrm{~cm}$, respectively) with the means for fifty-two plots in the region measured by Guldin, Baker, and Shelton (1994) of 16.0 and $26.5 \mathrm{~cm}$.

The total area of soil influenced by displacement can be estimated by assuming a circular area of influence with a diameter of twice the tree $\mathrm{dbh}$, such that this soil influence area $(\mathrm{SIA})=\pi(\mathrm{dbh})^{2}$. The SIA generally represents less than 1 percent of the surface area (Table 5).

\section{Relative Importance of Biomechanical Processes}

The relative importance of biomechanical effects of trees on soils in the Ouachitas can be examined based on the relative surface area involved. Acknowledging that the field data are a snapshot, we estimate below the proportion of the forest surface area influenced by uprooting, stump rot (or combustion), and soil displacement (baumsteins) using two different approaches.
In the first approach, the proportional area influenced by uprooting is estimated based on the surface area measured from rootwads. For stump holes, the area is estimated based on the basal area of stumps and snags. For soil displacement by tree growth, the area is based on the basal area of baumstein trees divided by the rock fragment cover. This has the effect of applying the basal area of rock-displacing trees per unit area to the entire plot. The reasoning is that although only displacement indicated by baumsteins was measured, comparable displacement is occurring throughout the plot. This is an underestimate, both because baumsteins were recorded only if fragments $>6 \mathrm{~cm}$ diameter were present, and because trees may be denser in areas with lower surface rock fragment concentrations. Uprooting, in particular, may be highly episodic; the major uprooting mechanism in the region is ice storms, and a major ice storm occurred in 2000. Thus, uprooting inventories conducted in 2001 and 2002 should provide a reasonable snapshot of stands likely to experience significant uprooting. Results are shown in Table 6.

The second approach is based on the basal area of trees in the region, with the following assumptions:

1. All trees displace soil, whether or not rock fragments are present.

2. The SIA for a given tree is equal to a circle whose diameter is twice the tree dbh (a conservative estimate).

3. All trees that attain sufficient age will ultimately result in either stump holes or uprootings.

Based on fifty-two stands in the Ouachitas, Guldin, Baker, and Shelton (1994) report a mean of 798 trees $\mathrm{ha}^{-1}$, of which 51 percent are pines and 49 percent hardwoods. The SIA for the pine and hardwood of mean $\mathrm{dbh}$ is 0.221 and $0.154 \mathrm{~m}^{2}$, respectively. Multiplying 
Table 6. Surface area affected by threethrow, stump rot, and displacement

\begin{tabular}{|c|c|c|c|c|c|c|}
\hline & \multicolumn{2}{|c|}{ Mean } & \multicolumn{2}{|c|}{ Maximum } & \multicolumn{2}{|c|}{ Minimum } \\
\hline & Area $\left(\mathrm{m}^{2}\right)$ & Proportion & Area $\left(\mathrm{m}^{2}\right)$ & Proportion & Area $\left(\mathrm{m}^{2}\right)$ & Proportion \\
\hline Treethrow & 2.40 & 0.0019 & 8.9 & 0.0070 & 0 & 0 \\
\hline Stump rot & 0.57 & 0.0004 & 1.53 & 0.0012 & 0.14 & 0.0001 \\
\hline Baumstein (rock fragment displacement) & 30.86 & 0.0243 & 129.79 & 0.1022 & 11.43 & 0.0090 \\
\hline
\end{tabular}

Notes: Means are for all study plots; maximum and minimum are values for the plots with the highest and lowest proportions, respectively, of each phenomenon. Plot area is $1,270 \mathrm{~m}^{2}$.

these by the mean number of pine and hardwood stems per hectare, we estimate that 1.5 percent of the surface area is influenced by soil displacement by tree growth.

The relative numbers of stumps and uprootings (Table 3) suggests that 93 percent of trees would become standing dead rather than uprooting. Assuming a mean basal area of $25 \mathrm{~m}^{2} \mathrm{ha}^{-1}$ (see Table 4), 93 percent implies $23 \mathrm{~m}^{2} \mathrm{ha}^{-1}$ of stump holes $(0.23$ percent of the surface area).

Mean surface area of individual uprootings (Table 3) is $1.84 \mathrm{~m}^{2}$. Mean basal areas for individual trees (Table 4) is about $0.036 \mathrm{~m}^{2}$, implying that surface area of uprootings is, on average, about fifty-one times that of the tree basal area. Based on this, 7 percent of $25 \mathrm{~m}^{2} \mathrm{ha}^{-1}$ uprooted would produce $89.25 \mathrm{~m}^{2} \mathrm{ha}^{-1}$ of disturbance or 0.89 percent of the surface area.

\section{Discussion}

Forest soils are profoundly influenced by vegetation, and these influences include biomechanical as well as chemical and biological processes. Studies of biomechanical impacts of trees have focused mainly on uprooting, but results from this study suggest that at least two other effects are significant: the physical displacement of soil material by root growth, and infilling of stump rot pits or depressions.

The subtitle of this study (Beyond Treethrow) is intended to indicate the sigificance of other biomechanical processes in addition to uprooting, and we do not suggest that treethrow is not important in the Ouachita Mountain study area. Uprooting is indeed quite important in soil and regolith evolution, as indicated in this and earlier work (Phillips and Marion 2004a, 2004b; Phillips, Luckow, et al. 2005). Rather, the task here has been to determine the efficacy of displacement and stump rot, as uprooting has been far more extensively studied.

Other than mounds at the bases of existing trees, soil displacement is difficult to observe and quantify. At the study sites the rocky soils allowed us to use rock fragments as a tracer of displacement, as well as to explicitly address effects of trees on rock fragment movement. Displacement, as indicated by baumsteins, is ubiquitous, and is underestimated in this study by restricting the baumstein inventory to cases where at least one displaced clast is $\geq 6 \mathrm{~cm}$ in median diameter. This supports the conceptual model of soil as a continuously-stirred biomantle, and, to the extent these results apply to other forests, indicates that tree growth is an important part of this mixing.

Displacement occurred in association with all tree types, but the characteristic differences between pines and hardwoods suggest that vegetation changes may be associated with changes in the style of displacement. Hardwoods promote primarily lateral displacement, with a higher probability of displaced rock fragments eventually falling into stump holes. Pine displacement has a significant vertical component associated with basal mounding, and a lower probability of baumstein fragments ending up in stump holes.

Rock fragments at the study sites are primarily derived from upslope outcrops and ridgetops, and the number of baumsteins is related to the proportion of surface fragment cover. The data suggest that most surface fragments in contact with trees are indeed being displaced by tree growth rather than becoming lodged against trunks through mass wasting. The prevalence of continuous rock rings (34 percent of baumsteins) indicates that in some cases trees may create a form of patterned ground (Figure 8).

Although unambiguous stump holes were relatively rare, the high ratio of stumps and snags to uprootings indicates that standing mortality, which would ultimately result in a stump hole, is quite common at our sites. This, plus the presence of numerous duff-filled depressions that could not be confidently identified as stump holes using our conservative field criteria, suggests that the holes are filled rapidly. The presence of surfacederived rock fragments in every hole and thick litter and duff accumulations indicates that at least some of the fill is external, as opposed to slumping of the soil surrounding the pit. Localized subsurface stone accumulations are also consistent with this interpretation. 


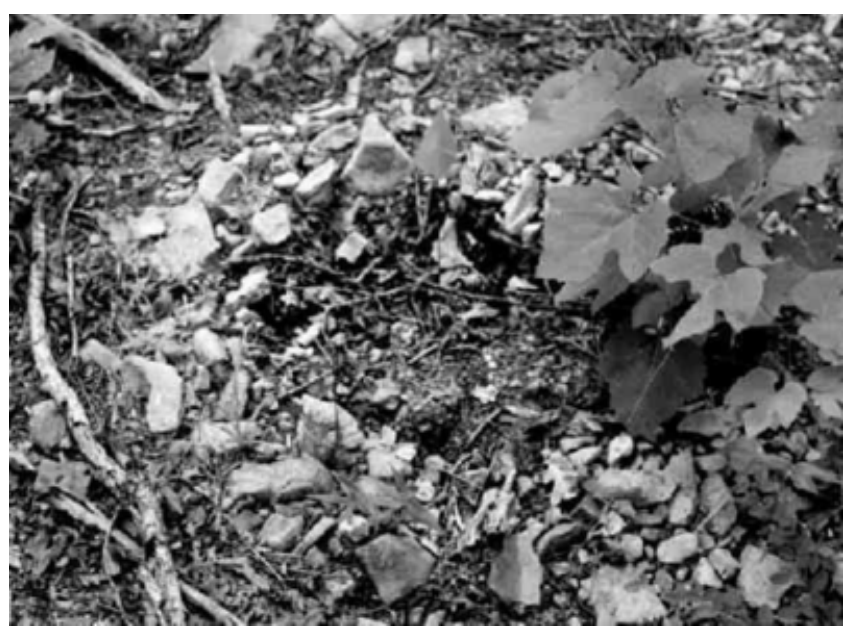

Figure 8. Stone ring created by displacement due to tree growth, and left behind after tree mortality.

Although standing mortality is much more prevalent than uprooting, the total area affected by treethrow is large due to the greater area of disturbance per event.

In terms of the total amount of soil disturbance, physical displacement affects the greatest area, followed by uprooting, and stump hole infilling. Even the latter, however, influences a significant volume of soil, with a surface area of more than $20 \mathrm{~m}^{2} \mathrm{ha}^{-1}$ (Table 7) and depth dimensions equal to the depth of tap roots, which in most cases is approximately equal to soil thickness (Phillips, Marion, et al. 2005).

The contemporary rate of soil disturbance cannot be confidently extrapolated. However, estimating the turnover time (the time for 100 percent of the forest floor to be affected) provides a means to gain an appreciation of the efficacy of the biomechanical influences of trees. Besides being a conveniently round number, Bragg's (2004) study of historic forest composition changes in the area, and Guldin, Baker, and Shelton's

Table 7. Disturbance by uprooting (treethrow), stump rot, and soil displacement, and estimated time to affect entire forest surface

\begin{tabular}{lccc}
\hline & $\begin{array}{c}\text { Disturbance area } \\
\left(\mathrm{m}^{2} \mathrm{ha}^{-1}\right)\end{array}$ & $\begin{array}{c}\text { Proportion } \\
\text { of area }\end{array}$ & $\begin{array}{c}\text { Time to } \\
\text { affect entire } \\
\text { surface }^{\text {a }} \text { (years) }\end{array}$ \\
\hline Uprooting & 89 & 0.0089 & 11,235 \\
Stump rot & 23 & 0.0023 & 43,478 \\
Soil displacement & 160 & 0.0160 & 6,250 \\
Combined & 272 & 0.0272 & 3,676 \\
\hline
\end{tabular}

Note: Based on assumption that all trees displace soil and are uprooted or undergo standing death in the same proportion as in the study plots (see the text for discussion).

${ }^{\mathrm{a}}$ Time $=(100$ percent of area $) \times(100 \mathrm{yr} /$ proportion of area $)$.
(1994) data on tree ages suggest that one-hundred years is not an unreasonable first-cut estimate of forest turnover time. As a first approximation, if we assume that the disturbance areas listed in Table 7 are those that would occur every one-hundred years (the estimated life span of one generation of forest trees), then the estimated time it would take for each process to affect 100 percent of the forest ground surface would be 11,235 years for uprooting, 43,478 years for stump rot, and 6,250 years for soil displacement. Table 7 suggests a total of $272 \mathrm{~m}^{2}$ $\mathrm{ha}^{-1}$ of biomechanical soil disturbance area. If this is interpreted as the area affected per generation of forest, with a one-hundred-year generation age an area equivalent to the entire surface area would be affected every 3,676 years. We recognize that all areas of the surface are not necessarily influenced by tree effects (Phillips and Marion 2004b), that the contemporary data represent a snapshot that may not be representative of earlier (or future) conditions, and that the assumptions with respect to forest replacement times are debatable. However, the calculation should serve to make the point that biomechanical effects of trees are potentially capable of influencing essentially the entire forest soil over Holocene time scales.

As alluded to earlier, and discussed at length by Phillips and Marion (2004b), pedological effects of trees are spatially heterogeneous, even over multiple generations of forest. The displacement and stump hole phenomena likely contribute to divergent soil evolution in which relatively tree-rich patches are repeatedly influenced by displacement, stump rot, and uprooting, and relatively tree-poor microsites are less intensively influenced. Thus these results not only demonstrate the role of trees in creating a biomantle, but reinforce our view of individual trees as an important source of local-scale soil variability (Phillips and Marion 2004a).

The details of these results may not be relevant to other sites, or even to the Ouachitas under different climate and vegetation regimes. However, it seems likely that the biomechanical effects of trees, independently of uprooting, are significant in many forest environments. Subsurface growth must displace soil in many cases, and the mortality of any tree, by any means, must result in stumps that subsequently decompose or burn, or in uprooting.

Future work should address the infilling of stump holes in more detail. There is unquestionably surface material accumulating in these depressions, to varying extents, and in some cases pedologic and stratigraphic signatures of this infilling are evident. However, such evidence is not ubiquitous, suggesting that collapse of surrounding soil into the holes is important or that pe- 
dogeomorphic processes rapidly blur the effects of infilling, or both.

\section{Conclusions}

Past studies of the biomechanical effects of trees on soil have focused on uprooting, which is an important process in the Ouachita Mountains, Arkansas. This study shows, however, that two other processes are also significant: the physical displacement of soil by root and trunk growth, and the infilling of depressions created by stump rot. Displacement, stump holes, and uprooting help to maintain a continuously mixed surface layer or biomantle, and may in some cases result in distinctive pedological and geomorphological features. Further, they represent mechanisms by which individual trees create local spatial variations on soil morphology, and divergent evolution of the soil cover.

\section{Acknowledgments}

Nathan Phillips assisted in the fieldwork, and the University of Kentucky Cartography Laboratory in the preparation of figures. This project was supported by USDA Forest Service Cooperative grant SRS 04-CA11330124-140. Constructive critiques by Randy Schaetzl, Don Johnson, and David Butler resulted in substantial improvements.

\section{Note}

1. The five unused sites are all mixed pine/hardwood sites where the Ouachita National Forest is attempting to restore pine/bluestem savanna communities by a combination of hardwood thinning and controlled burns. These were not included in the present study due to the recent disturbance associated with the thinning.

\section{References}

Balek, C. L. 2002. Buried artifacts in stable upland sites and the role of bioturbation: A review. Geoarchaeology 17:41-51.

Bragg, D. C. 2004. Patterns of oak dominance in the eastern Ouachita mountains suggested by early records. In Upland oak ecology symposium: History, current conditions, and sustainability, ed. M. A. Spetich, 57-61. Asheville, NC: USDA Forest Service, Southern Research Station, General Tech. Rep. SRS-73.

Burns, R. M., and B. H. Honkala (compilers). 1990. Silvics of North America: 1. Conifers; 2. Hardwoods. Agriculture Handbook 654. Washington, DC: U.S. Department of Agriculture, Forest Service.

Butler, D. R., and G. P. Malanson. 1990. Non-equilibrium geomorphic processes and patterns on avalanche paths in the northern Rocky Mountains, U.S.A. Zeitschrift für Geomorphologie 34:257-70.
Delcourt, H. R., and P. A. Delcourt. 1991. Late-quaternary vegetation history of the interior highlands of Missouri, Arkansas, and Oklahoma. In Restoration of old growth forests in the interior highlands of Arkansas and Oklahoma: Proceedings of the conference; 19-20 September 1990; Morrilton, AR, ed. D. Henderson and L. D. Hedrick, 15-30. Hot Springs, AR: USDA Forest Service, Ouachita National Forest and Winrock International Institute for Agricultural Development.

Foti, T. L., and S. M. Glenn. 1991. The Ouachita Mountain landscape at the time of settelment. In Restoration of old growth forests in the interior highlands of Arkansas and Oklahoma: Proceedings of the conference; 19-20 September 1990; Morrilton, AR, ed. D. Henderson and L. D. Hedrick, 49-65. Hot Springs, AR: USDA Forest Service, Ouachita National Forest and Winrock International Institute for Agricultural Development.

Gabet, E. J., O. J. Reichmann, and E. W. Seabloom. 2003. The effects of bioturbation on soil processes and sediment transport. Annual Review of Earth and Planetary Sciences 31:249-73.

Guldin, J. M., J. B. Baker, and M. G. Shelton. 1994. Midstory and overstory plants in mature pine/hardwood stands of the Ouachita/Ozark National Forests. In Proceedings, Symposium on ecosystem mangement research in the Ouachita Mountains. Pretreatment conditions and preliminary findings, comp. J. B. Baker, 29-49. New Orleans: USDA Forest Service, Southern Forest Experiment Station, General Tech. Rep. $50-112$.

Guldin, J. M., and T. Foti. 2004. Baseline overstory conditions in four watersheds of varying management intensity in the eastern Ouachita mountains. In Ouachita and Ozark Mountains symposium: Ecosystem management research, comp. J. M. Guldin, 189-97. Asheville, NC: USDA Forest Service, Southern Research Station, General Tech. Rep. SRS-74.

Haley, G. J. 1979. Soil survey of Saline County, Arkansas. Washington, DC: U.S. Department of Agriculture.

Herwitz, S. R. 1993. Stemflow influences on the formation of solution pipes in Bermuda eolianite. Geomorphology 6: 253-71.

Johnson, D. L. 1990. Biomantle evolution and the redistribution of earth materials and artifacts. Soil Science 149:84-102.

. 1993. Biomechanical processes and the Gaia paradigm in a unified pedo-geomorphic and pedo-archaeologic framework: dynamic denudation. In Proceedings of the first international conference on pedo-archaeology, ed. J. E. Foss, M. E. Timpson, and M. W. Morris, 41-67. Knoxville: University of Tennessee Agricultural Experiment Station Special Publication 93-03.

. 2002. Darwin would be proud: Bioturbation, dynamic denudation, and the power of theory in science. Geoarchaeology 17:7-40.

Jordan, D. W., D. R. Lowe, R. M. Slatt, and C. G. Stone. 1991. Scales of geological heterogeneity of Pennsylvanian Jackfork Group, Ouachita Mountains, Arkansas: Applications to field development and exploration for deep-water sandstones. In Guidebook for the Dallas Geological Society field trip \#3. American Association of Petroleum Geologists 1991 annual convention; 4-7 April 1991, Dallas, TX. Little Rock: Arkansas Geological Commission: 1-20. Reprinted 1993.

Laurent, G. D., J. D. Chism, R. K. Rhodes, C. R. Wilson, and W. R. Townsend. 1989. Soil Survey of Garland County, Arkansas. Washington, DC: U.S. Department of Agriculture. 
Lutz, H. J., and F. S. Griswold. 1939. The influence of tree roots on soil morphology. American Journal of Science 237:389_ 400.

McFarland, J. D. 1998. Stratigraphic summary of Arkansas. Little Rock: Arkansas Geological Commission Information Circular 36.

Mossa, J., and B. A. Schumacher. 1993. Fossil tree casts in south Louisiana soils. Journal of Sedimentary Petrology 63:707-13.

Norman, S. A., R. J. Schaetzl, and T. W. Small. 1995. Effects of slope angle on mass movement by tree uprooting. Geomorphology 14:19-27.

Paton, T. R., G. S. Humphries, and P. B. Mitchell. 1995. Soils: A new global view. New Haven, CT: Yale University Press.

Phillips, J. D., K. Luckow, D. A. Marion, and K. R. Adams. 2005. Rock fragment distributions and regolith evolution in the Ouachita Mountains, Arkansas, USA. Earth Surface Processes and Landforms 30:429-42.

Phillips, J. D., and D. A. Marion. 2004a. Biomechanical effects, litholological variability, and pedodiversity in some forest soils of Arkansas. Geoderma 124:73-89.

- 2004b. Pedological memory in forest soil development. Forest Ecology and Management 188:363-80.

Phillips, J. D., D. A. Marion, K. Luckow, and K. R. Adams. 2005. Nonequilibrium regolith thickness in the Ouachita Mountains, Arkansas. Journal of Geology 113:325-40.

Pritchett, W. L., and R. F. Fisher. 1987. Properties and management of forest soils. New York: Wiley.

Scatena, F. N., and A. E. Lugo. 1995. Geomorphology, disturbance, and the soil and vegetation of two subtropical wet steepland watersheds of Puerto Rico. In Biogeomorphology, terrestrial and freshwater systems, ed. C. R. Hupp, W. R. Osterkamp, and A. D. Howard, 199-214. Amsterdam: Elsevier.

Schaetzl, R. J. 1990. Effects of treethrow microtopography on the characteristics and genesis of Spodosols, Michigan, USA. Catena 17:111-26.

Schaetzl, R. J., S. F. Burns, T. W. Small, and D. L. Johnson. 1990. Tree uprooting: Review of types and patterns of soil disturbance. Physical Geography 11:277-91.

Schaetzl, R. J., and L. R. Follmer. 1990. Longevity of treethrow microtopography: Implications for mass wasting. Geomorphology 3:113-23.
Shelton, M. G., and E. R. Lawson. 1994. Forest floor characteristics in mature pine-hardwood stands in the Ouachita Mountains. In Proceedings, Symposium on ecosystem mangement research in the Ouachita Mountains. Pretreatment conditions and preliminary findings, comp. J. B. Baker, 191-97. New Orleans: USDA Forest Service, Southern Forest Experiment Station, General Tech. Rep. 50-112.

Small, T. W. 1997. The Goodlett-Denny mount: A glimpse at 45 years of Pennsylvania treethrow mount evolution with implications for mass wasting. Geomorphology 18: 305-13.

Small, T. W., R. J. Schaetzl, and J. M. Brixie. 1990. Redistribution and mixing of soil gravels by tree uprooting. The Professional Geographer 42:445-57.

Stephens, E. P. 1956. The uprooting of trees-A forest process. Soil Science Society of America Proceedings 20:113-16.

Stone, C. G., and W. V. Bush. 1984. Summary of the geology of the central and southern Ouachita Mountains, Arkansas. In A guidebook to the geology of the central and southern Ouachita Mountains, Arkansas, ed. C. G. Stone and B. R. Haley, 65-75. Little Rock: Arkansas Geological Commission.

Thill, R. E., P. A. Tappe, and N. E. Koerth. 1994. Wildlife habitat conditions in mature pine-hardwood stands in the Ouachita/Ozark National Forests. In Proceedings, Symposium on ecosystem mangement research in the Ouachita Mountains. Pretreatment conditions and preliminary findings, comp. J. B. Baker, 126-43. New Orleans: USDA Forest Service, Southern Forest Experiment Station, General Tech. Rep. 50-112.

Townsend, W. R., and L. Williams. 1982. Soil survey of Perry County, Arkansas. Washington, DC: U.S. Department of Agriculture.

USDA Forest Service 1999. Ozark-Ouachita highlands assessment: Terrestrial vegetation and wildlife. Report 5 of 5 . General Technical Report SRS-35. Asheville, NC: USDA Forest Service, Southern Research Station. $201 \mathrm{pp}$.

Vasenev, I. I., and V. O. Targul'yan. 1995. A model for the development of sod-podzolic soils by windthrow. Eurasian Soil Science 27:1-16.

Correspondence: Department of Geography, University of Kentucky, Lexington, KY 40506-0027, e-mail: jdp@uky.edu (Phillips); Southern Research Station, USDA Forest Service, P.O. Box 1270, Hot Springs, AR 71902, e-mail: dmarion@fs.fed.us (Marion). 